\title{
Tulane
}

\author{
Tulane Economics Working Paper Series
}

\section{Do eBay Sellers Comply with State Sales Taxes?}

\author{
James Alm \\ Department of Economics \\ Tulane University \\ New Orleans, LA \\ jalm@tulane.edu
}

\author{
Mikhail I. Melnik \\ Department of Commerce \\ College of Business Administration \\ Niagara University \\ Niagara University, NY \\ mmelnik@niagara.edu
}

\section{Working Paper 1106}

April 2011

\begin{abstract}
The rapid growth in online commerce has harmed state sales tax bases. However, the extent of this base reduction is difficult to estimate. In this paper we collect our own data from eBay.com on a "representative" commodity classification and a "typical" day. Our data consist of nearly twenty-one thousand eBay listings generated by over seven thousand individual sellers with over ninety-three hundred buyers. We find that overall eBay seller compliance is quite low but that compliance by established sellers is significantly higher. Given that established sellers account for the bulk of online commerce, the estimated revenue loss from eBay seller noncompliance may be relatively small.
\end{abstract}

Keywords: online commerce, sales taxes, nexus, tax evasion

JEL: H26, H71 


\title{
DO EBAY SELLERS COMPLY WITH STATE SALES TAXES?
}

\author{
James Alm and Mikhail I. Melnik
}

\section{SUMMARY}

Online commerce has increased enormously in recent years, much more rapidly than the overall growth of retail sales even though online retail sales remain a relatively small percentage (3.6 percent) of total retail sales. This development has harmed state (and local) sales tax bases, due to the current legal interpretation that does not require out-of-state vendors to collect state sales taxes on behalf of any state where they have no legal presence (or "nexus"). There is some evidence this erosion has contributed to revenue declines for these governments, but this evidence remains somewhat speculative. It is quite difficult to know the actual impact of revenues due to difficulties in measuring the compliance of vendors with state sales and excise taxes.

Several methods have been used to generate some notion of these revenue losses. Some studies employ a somewhat indirect procedure, using estimates of consumer responses to sales tax rates to estimate the likely impact of the revenue loss with the application of online sales taxes, or examining tax-induced cross-border shopping. These studies imply, but do not directly estimate, that sales tax revenue losses are likely to be important. Several other studies actually estimate the revenue loss from online sales, typically by estimating the time trend reduction in state government sales tax bases that occurred independently of e-commerce, and then also estimating the additional revenue loss from e-commerce. These studies conclude that sales tax revenues fell due to online commerce. Even so, this approach is still largely an indirect one. In yet another approach, aggregate online retail spending data are now being gathered and analyzed by a number of consulting firms. However, the lack of information at the individual consumer level, especially about the specific location of the consumer, makes an investigation into the impact of the tax rates on retail e-commerce quite difficult.

In this paper we use a different, and more direct, approach. We collect our own data from eBay.com on a "representative" commodity classification and a "typical" day. eBay is by far the largest online consumer-to-consumer and business-to-consumer marketplace in the United States. Specifically, we collect data on one category of eBay listings, "Consumer Electronics", sold on eBay over a 24-hour period in summer 2007. These data consist of more than twenty-one thousand eBay listings generated by over seven thousand individual sellers with over ninetythree hundred buyers, all taking place in a 24-hour period of time in just a fraction of one category of the U.S. eBay website. We use these data to answer several questions. First, how many sellers actually collect state sales taxes? Second, what is the revenue loss from the seller noncompliance? Third, is seller noncompliance related to specific factors, like seller characteristics or the level of state sales tax rates?

We find that overall eBay seller compliance is quite low, but that compliance by established sellers is significantly higher. Given that established sellers account for the bulk of online commerce, the estimated revenue loss from seller noncompliance is relatively small. 


\title{
DO EBAY SELLERS COMPLY WITH STATE SALES TAXES?
}

\author{
James Alm and Mikhail I. Melnik
}

The rapid growth in online commerce has harmed state sales tax bases. However, the extent of this base reduction is difficult to estimate. In this paper we collect our own data from eBay.com on a "representative" commodity classification and a "typical" day. Our data consist of nearly twenty-one thousand eBay listings generated by over seven thousand individual sellers with over ninety-three hundred buyers. We find that overall eBay seller compliance is quite low but that compliance by established sellers is significantly higher. Given that established sellers account for the bulk of online commerce, the estimated revenue loss from eBay seller noncompliance may be relatively small.

Keywords: online commerce, sales taxes, nexus, tax evasion

JEL Codes: H26, H71

James Alm: Department of Economics, Tulane University, 6823 St. Charles Avenue, 208 Tilton Hall, New Orleans, LA 70118 (phone 504862 8344; fax 504865 5869; email jalm@tulane.edu)

Mikhail I. Melnik: Department of Commerce, College of Business Administration, P.O. BOX 2201, Bisgrove Hall, Niagara University, Niagara, NY 14109-2201 (phone 716286 8311; fax 716286 8206; email mmelnik@niagara.edu) 


\section{INTRODUCTION}

Online commerce has increased enormously in recent years. According to estimates from the United States Census Bureau (2009), online retail sales grew between 2002 and 2007 at an average annual rate of 23.1 percent, almost five times the overall growth of retail sales during the same period, even though online retail sales remain a relatively small percentage (3.6 percent) of total retail sales in 2009. This development has harmed state (and local) sales tax bases, due to the current legal interpretation that does not require out-of-state vendors to collect state sales taxes on behalf of any state where they have no legal presence (or "nexus"). ${ }^{1}$ There is some evidence this erosion has contributed to revenue declines for these governments, but this evidence remains somewhat speculative. It is quite difficult to know the actual impact of revenues due to difficulties in measuring the compliance - or noncompliance - of vendors with state sales and excise taxes. ${ }^{2}$ In this paper we use a direct approach to estimate the revenue loss, by collecting our own data from eBay.com on a "representative" commodity classification and a "typical" day. We find that overall eBay seller compliance is quite low but that compliance by established (and larger) sellers is significantly higher, so that the estimated revenue loss from seller noncompliance may be small.

Several methods have been used to generate some notion of the revenue losses from ecommerce. One approach employs a somewhat indirect procedure, using estimates of consumer

\footnotetext{
${ }^{1}$ See Quill vs. North Dakota, 112 US 298 (1992). Such internet transactions are in principle still subject to a state use tax, imposed at the same rate as the state sales tax. However, the extent of noncompliance with state use taxes is believed to be quite large.

2 The threat emerging from e-commerce has sparked a number of debates among public policy makers. For example, the National Governors Association has advocated a more uniform sales tax structure in the U.S., one that would be more easily adaptable by out-of-state vendors. While the uncertainty about the implementation of such reform still exists, most states continue to experience ongoing budgetary problems, and are forced to look for immediate solutions. Some states have begun to consider increases in sales tax rates as a response to the shrinking tax revenue problem. However, it is feared that such a response in light of the current tax treatment of e-commerce may cause a further deterioration in the sales tax base. See Luna and Fox (2000), Cornia, Sjoquist, and Waters (2005), and Fox, Luna, and Murray (2008) for useful discussions of many of these debates.
} 
responses to sales tax rates to estimate the likely impact of the revenue loss with the application of online sales taxes. Goolsbee (2000) uses individual survey data from Forrester Research to estimate the impact of sales tax rates on the likelihood that individual consumers purchase online. He finds that sales tax rates have a positive and statistically significant impact on the amount of online consumer spending, and concludes that taxing internet sales could reduce the number of online buyers by 24 percent. Alm and Melnik (2005) use a more recent, larger, and more representative data set from a special supplement to the Current Population Survey (CPS), and they also find that a higher sales tax rate increases the probability that consumers purchase online. However, their estimate of this impact is much smaller (roughly one-fourth) than the Goolsbee (2000) estimate, so that they conclude that taxing internet sales would reduce online purchases by only 6 percent. Scanlan (2007) also finds in some specifications a small and insignificant relationship between sales tax rates and the likelihood of online purchases; however, he also estimates a larger and significant response when he uses a splined tax-rate function, at least for consumers living in high sales tax rate areas. In perhaps the most comprehensive empirical study, Ballard and Lee (2007) also use the special supplement to the CPS to obtain estimates of consumer responses to sales tax rates. Like Goolsbee (2000), Alm and Melnik (2005), and Scanlan (2007), Ballard and Lee (2007) conclude that consumers use the internet to avoid paying sales taxes, with responses roughly similar to those of Alm and Melnik (2005). By implication, all three studies imply that sales tax revenue losses are likely to be important, although none of the studies actually estimates these losses.

Another indirect approach examines tax-induced cross-border shopping. Here consumers respond to differentials in sales tax rates, lottery payoffs, and/or exchange rates between neighboring jurisdictions, by crossing the relevant border and purchasing items in the lower-cost 
jurisdiction (just as they do in purchasing online rather than from traditional vendors). FitzGerald (1992) estimates such responses for Ireland and the United Kingdom, as do Gordon and Neilson (1997) for Denmark, Ferris (2000) for Canada and the U.S., and Garrett and Marsh (2002) for Kansas and neighboring states. All of these studies conclude that taxes (and other sources of price differentials) have a significant impact on consumer choices. By implication, these studies also suggest that revenue losses from e-commerce are likely to be significant.

Several other studies actually estimate the revenue loss from online sales. In the best example of this methodology, Bruce and Fox $(2000,2001,2004)$ estimate the time trend reduction in state government sales tax bases that occurred independently of e-commerce, and they also estimate the additional revenue loss from e-commerce. ${ }^{3}$ They conclude that sales tax revenues fell in 2003 by over $\$ 13$ billion from the trend line of revenues, or nearly 2 percent of actual revenues in that year; they also conclude that e-commerce caused an additional reduction in sales tax revenues of nearly $\$ 11$ billion (1.5 percent of revenues) in 2003. More recently, Bruce, Fox, and Luna (2009) supplement this approach with detailed state-by-state survey estimates of the degree to which e-commerce transactions are taxable in each state, and estimate that annual national state and local sales tax losses on e-commerce will grow to roughly $\$ 11-13$ billion by 2012. These estimates may be the best current estimates of the likely revenue loss, but they have not gone unchallenged. ${ }^{4}$ Even so, this approach is still largely an indirect one.

\footnotetext{
${ }^{3}$ More precisely, Bruce and Fox $(2000,2001,2004)$ estimate the time trend reduction in revenues by: calculating the state sales tax base; estimating the relationship between the calculated base and personal income; forecasting personal income growth; forecasting the sales tax base using the personal income forecast; using the resulting forecast sales tax base to calculate a trend-line of sales taxes; and finally comparing actual sales tax revenues to forecast revenues to generate the trend line revenue losses. They estimate the revenue loss from e-commerce by using Forester Research estimates of the decline in sales tax bases due to e-commerce and by then applying sales tax rates to the resulting tax base declines.

${ }^{4}$ See, for example, various studies by the Direct Marketing Association (DMA), available at http://www.thedma.org/index.php . In its words, the DMA is "...the leading global trade association of business and nonprofit organizations using and supporting multichannel direct marketing tools and techniques". The DMA studies by Johnson $(2003,2008)$ conclude that the revenue losses are likely to be significantly smaller than the estimates of Bruce and Fox $(2000,2001,2004)$ and Bruce, Fox, and Luna (2009).
} 
In yet another approach, aggregate online retail spending data are now being gathered and analyzed by a number of different consulting firms. ${ }^{5}$ However, the lack of information at the individual consumer level, especially about the specific location of the consumer, makes an investigation into the impact of the tax rates on retail e-commerce quite difficult. ${ }^{6}$

In this paper we use a different, and more direct, approach. We collect our own data from eBay.com on a "representative" commodity classification and a "typical" day. eBay is by far the largest online consumer-to-consumer and business-to-consumer marketplace in the United States. Specifically, we collect data on one category of eBay listings, "Consumer Electronics", sold on eBay over a 24-hour period in summer 2007. These data consist of more than twenty-one thousand eBay listings generated by over seven thousand individual sellers with over ninetythree hundred buyers, all taking place in a 24-hour period of time in just a fraction of one category of the U.S. eBay website. Our data have some limitations, as we discuss in detail later. Even so, to our knowledge this is one of the largest datasets ever collected from eBay for academic research.

We use these data to answer several questions. First, how many sellers actually collect or do not collect - state sales taxes? Second, what is the revenue loss from the seller noncompliance (where the seller appears to have a sales tax collection obligation)? Third, is seller noncompliance related to specific factors, like seller characteristics or the level of state sales tax rates? We find that overall eBay seller compliance is quite low, but that compliance by

\footnotetext{
${ }^{5}$ For example, see estimates provided by Forrester Research (http://www.forrester.com), GartnerG2 (http://www.gartnerg2.com), and Jupiter Media Matrix (http://www.jupiterresearch.com). Also, see the eMarketer website (http://www.emarketer.com) and the ePayments website (http://www.epayments.com).

${ }^{6}$ Also, see Fox and Murray (1997) and Goolsbee and Zittrain (1999) for discussions of various issues about the taxation of electronic commerce.
} 
established sellers is significantly higher. Given that established sellers account for the bulk of online commerce, the estimated revenue loss from seller noncompliance is relatively small. ${ }^{7}$

The next section presents our approach and gives some summary statistics on our dataset. Our main results are discussed in the section III, and our conclusions are in the final section.

\section{APPROACH AND DATA}

For several years now eBay has been the leading online consumer-to-consumer and business-to-consumer e-commerce community. In the first quarter of 2009 (January - March), the volume of completed transactions excluding autos on the eBay marketplace exceeded $\$ 10.7$ billion, and the number of active users surpassed 88.3 million. ${ }^{8}$ With such a volume of trade, eBay is easily the largest single online marketplace in the United States, even though online retail sales remain a relatively small percentage (3.6 percent) of total retail sales in 2009 . When one focuses on the third quarter of 2007 (or our period of observation), total e-commerce sales were estimated by a U.S. Department of Commerce survey of some 12,500 retailers at $\$ 31.7$ billion, about 3.5 percent of the total retail sales for the quarter, and eBay transactions in the third quarter of 2007 constituted more than 33 percent of the survey's online retail sales. ${ }^{9} 10$

\footnotetext{
${ }^{7}$ As discussed in more detail later, it is important to note that our work focuses on seller noncompliance. Our data do not provide any information on buyer compliance with any use tax that might exist in the jurisdiction. As a result, we are unable to compute state revenue losses due to cross-border shopping.

${ }^{8}$ See eBay's First Quarter 2009 Financial Results, available online at http://investor.ebay.com/financial releases.cfm.

${ }^{9}$ See the Quarterly E-commerce Retail Sales, ${ }^{\text {rd }}$ Quarter of 2007, published by the U.S. Department of the Census. This information is based on a survey of about 12,500 retail firms, and is available online at http://www.census.gov/mrts/www/data/html/09Q1.html .

${ }^{10}$ For example, the volumes of total retail sales, total e-commerce sales, and total eBay sales in recent quarters (each in millions of dollars) are:

\begin{tabular}{|l|c|c|c|}
\hline Period & Total Retail Sales & Total E-commerce Sales & Total eBay Sales \\
\hline $2009, \mathrm{Q} 3$ & 922,178 & 34,030 & 12,192 \\
\hline $2009, \mathrm{Q} 2$ & 906,440 & 32,557 & 11,127 \\
\hline $2009, \mathrm{Q} 1$ & 909,867 & 31,708 & 10,797 \\
\hline $2008, \mathrm{Q} 4$ & 924,493 & 31,482 & 11,470 \\
\hline
\end{tabular}
}


Also, eBay is much more than an outlet for individual consumers reselling items that they no longer need. A large portion of eBay transactions is generated by businesses, small and large alike. For example, as we discuss in more detail later, our dataset includes items sold by small businesses as well as items sold by national retail chains such as BestBuy. Bailey et al. (2008) argue that this unique characteristic of eBay as a market place within the online commerce leads to large entry by small businesses, and may in turn lead to a bias toward significant underestimation of online sales in the Census Bureau estimates of online commerce because these estimates do not pick up small sellers. The findings of Bailey et al. (2008) further underscore the importance of investigating the size of commerce on eBay and subsequently seller sales tax compliance on eBay.

The large volume of transactions on eBay makes it nearly impossible to get a clear picture of total sales tax compliance in the entire online community. The role of eBay is limited mainly to that of a market facilitator. eBay is not the seller of the product, which removes any responsibility for sales and excise tax collecting or monitoring from eBay itself. Indeed, eBay does not report any tax-related statistics in any of its news releases.

However, eBay apparently understands the importance of sales tax collection for sellers. Indeed, eBay provides sellers with an option to apply state sales taxes at the time of the listing of the item, and many sellers in fact select this option. ${ }^{11}$ In our dataset nearly one in five sellers collected sales taxes, and 93 percent of those sellers selected the eBay-offered option of indicating sales taxes. However, this appears to be the full extent of eBay's role in the tax

\begin{tabular}{|l|c|c|c|}
\hline $2008, \mathrm{Q} 3$ & 997,086 & 33,426 & 11,361 \\
\hline $2008, \mathrm{Q} 2$ & $1,033,794$ & 34,237 & 12,301 \\
\hline $2008, \mathrm{Q} 1$ & $1,025,344$ & 33,645 & 12,868 \\
\hline $2007, \mathrm{Q} 4$ & $1,025,957$ & 33,531 & 13,107 \\
\hline $2007, \mathrm{Q} 3$ & $1,015,408$ & 32,504 & 11,108 \\
\hline
\end{tabular}

Source: United States Census Bureau (2009).

${ }^{11}$ The seller also has an option to specify the exact sales tax rate. 
collection process. Business-to-consumer transactions on eBay are subject to any applicable state and local sales taxes, and sellers who have a nexus in any sales tax state are required to collect the sales tax from any instate transactions that originate on eBay, just as they would had those transactions been done in their "brick and mortar" stores. ${ }^{12}$ Sales tax collection, much like any other terms of the transaction, has to be included in the listing, as the listing information acts as a binding contract between the buyer and the seller on eBay.

The setup of the eBay sales tax option is quite simple. At the time the listing is submitted by the seller, the seller can select to apply state sales taxes to the winning bid. If this option is selected by the seller, then the seller must select the state for which the sales tax will be collected, and a message stating the sales tax rate and applicable state will be automatically included by eBay in the payment/shipping section of the listing. Alternatively, a seller who chooses to collect sales taxes may simply include this information as a message in the item description text of the auction. Most sellers in our dataset do not collect sales taxes. However, nearly all the sellers in our dataset who do collect sales taxes (more than 93 percent) do so using the eBay-provided option. For sellers, the eBay-provided option may also serve as a better mechanism because the sales tax information will be included in the eBay payment notification email sent to the buyer, thereby making it part of a binding contract between the buyer and the seller, as based on eBay's rules.

The lack of eBay-provided information and the sheer number of listings suggest a limited survey of the transactions on eBay as an appropriate method of investigation into the crossborder commerce on eBay and the sales tax collection by eBay sellers. This is our approach here. We use data that we collected from eBay, and we limit our investigation to items listed in most

\footnotetext{
${ }^{12}$ For sellers who listed several states as their nexus, we define instate transactions as the ones where the buyer is located in any one of the seller's nexus states.
} 
of the subcategories of the "Consumer Electronics" category that closed on Friday, 27 July 2007. We focus on the Consumer Electronics category in large part because the products sold in this category do not appear to be tax exempt or subject to any excise taxes in any of the sales tax states (Bruce, Fox, and Luna, 2009). Furthermore, there were no sales tax holidays on 27 July 2007, which might cause state differences in the tax treatment of these products.

Consumer Electronics is one of 35 major categories on eBay. Table 1 provides a summary of these categories. These numbers indicate clearly the relative importance of these categories in terms of the number of listings.

At the time of our data collection in 2007, the category of "Consumer Electronics" was comprised of seventeen subcategories, since then the category has undergone small changes. In 2008 the category was renamed to simply "Electronics", and the number of categories was expanded to 20, as three new categories were introduced (Marine Audio, Pro Audio and Stage Effects, and Other). Table 2 lists the subcategories during the period of our data collection (27 July 2007), along with the number of listings for two days in January $2008 .{ }^{13}$ These comparative dates are presented in order to demonstrate the representativeness of the date of our original data collection.

Interestingly, there was significant growth in the number of listings in the Consumer Electronics subcategories between 27 June 2007 and 6-7 January 2008, as seen in Table 2, a

\footnotetext{
${ }^{13}$ A more recent summary of the number of daily listing closings in the Electronics category by day for the period of 1-7 May 2009 also indicates the representativeness of our data:

\begin{tabular}{|c|c|}
\hline Date & Listings Completed \\
\hline May 1 & 78076 \\
May 2 & 66435 \\
May 3 & 78212 \\
May 4 & 80572 \\
May 5 & 77912 \\
May 6 & 76037 \\
May 7 & 74778 \\
\hline
\end{tabular}
}


result that is consistent with the overall growth of eBay in that period. However, the relative importance of these subcategories within the category remained relatively stable. ${ }^{14}$ Also, the growth in listings slowed in the 2008-09 period. Both results are in line with the overall performance of the eBay market place, which saw reductions in the value of goods traded throughout the first three quarters of 2008 (eBay Quarterly Financial Releases for 2008).

Table 3 presents the detailed summary by subcategory of the observations collected on 27 July 2007. We were able to collect data on eleven of the seventeen subcategories of Consumer Electronics on eBay mainly because the data were only available for a period of two weeks (see the discussion below). The data consist of more than twenty-one thousand eBay listings generated by over seven thousand individual sellers with over ninety-three hundred buyers, all taking place in a 24-hour period of time in just a fraction of one category of the U.S. eBay website. ${ }^{15}$ Note that eBay generally removes all auctions from the search page that is visible to the public two weeks after their completion, which effectively constrains any data identification process. Although these listings generally remain accessible to the public up to ninety days after their completion, their lack of appearance on the search page makes locating them impossible without their eBay-assigned listing identification numbers.

Table 4 presents basic summary statistics. We use the same terminology as eBay when we use "Listing", which eBay defines as a contract between the seller and eBay where eBay agrees to display the seller's item (s) for sale. Each listing on eBay is assigned its own unique identification number. However, a listing can result in multiple transactions. Consequently, a "Listing" and an "Observation" may not be equivalent. In our analysis we count the number of transactions by the number of unique buyers. If a listing only has one item for sale, then it can

\footnotetext{
${ }^{14}$ The number of all listings on eBay increased by 16 percent between the second quarter of 2007 and the first quarter of 2008; see eBay First Quarter of 2008 Financial Release (http://investor.ebay.com/financial releases.cfm).

${ }^{15}$ We are grateful to Robert Buschman and Andrew Chupp for their work in collecting these data.
} 
only result in one transaction; however, for a multi-item listing, it is possible to have multiple winning buyers. ${ }^{16}$ For example, if a best- offer listing results in one buyer purchasing one unit at $\$ 10$ and another buyer buying two units at $\$ 9$ each, we count these as two separate transactions, one valued at $\$ 10$ and another at $\$ 18$, even though the listing itself is counted only once by eBay and by us. This enables us to identify clearly the size of transactions between buyers and sellers and hence to measure the size of in-state and out-of-state commerce generated on eBay in the categories represented in our dataset. Note that, if a listing receives no bids, it is still included as an observation because it contains information about the seller's choice of tax policy.

Table 4 also presents information on seller and buyer composition. When collecting the data, we specifically limit the search to only those listings that originate in the U.S.; eBay provides this option on its search page. Even so, a number of foreign sellers are still included in our data because these sellers stated in the auction description that the item offered for sale was located in the U.S. In total there are 33 foreign sellers in the dataset, and for 32 sellers we are unable to establish their location. For buyers the missing locational data are more common, and we could not identify the location of 494 buyers.

Table 5 presents additional descriptive statistics. "Price" represents the price at the time of the closing of the auction. We report the price for the entire dataset and also separately for the successfully completed segment only. "Sold" is a binary variable that assumes the value of one if the item sold and zero otherwise. "Observations Per Seller" refers to the number of observations generated by the seller. On average, each seller generates 36 observations, with one seller generating 306 observations. Such sellers are likely to be business entities, and seem more likely

\footnotetext{
${ }^{16}$ eBay offers various selling mechanisms to its sellers: standard English auction format, which may include multiple items but has a single buyer; buy-it-now format, which may include multiple items and may have multiple buyers all paying the same price; and best offer option, which may include multiple items and may have multiple buyers with prices that may differ across buyers.
} 
to collect sales taxes. We also report in Table 5 "Seller Rating", a feedback measure from the past experience of the seller on eBay. This measure is based on the number of unique transactions with different eBay users, and can act as a proxy for the business status of the seller. Sellers with high feedback have had substantial transaction experience, and so are more likely to be established businesses; for example, the BestBuy outlet had a rating of nearly 31,000 at the time of our data collection. The average of "Seller Rating" is first computed with respect to the number of observations and then with respect to the number of sellers; the second value represents the average seller rating, while the first represents the average seller rating per listing. The sharp difference in the values suggests that more established sellers sell more items on eBay. More precisely, we define "Established Sellers" as eBay sellers with 1000 rating points and higher.

"Taxation" is a binary variable that equals one if the seller collects sales taxes and zero otherwise. The data show that sales taxes are listed in 43 percent of all of our listings. On the surface, this represents a very high compliance level. However, when we examine individual seller compliance, we find that only about 18 percent of all sellers choose to list sales taxes. Together with the observation from the "Seller Rating", this suggests that established sellers are more likely to collect sales taxes and also to list more items.

Since not all sellers select the eBay option of identifying sales taxation, we had to monitor individual auction descriptions for those auctions that missed the eBay option. In order not to miss the sellers who do not select the eBay option but who still list the sales taxes in the description of the item section of the auction, we visit all individual observations for all sellers with $100+$ rating points and for all sellers with more than one observation, and their descriptions are examined for any relevant sales tax information. 


\section{RESULTS}

Recall that we are interested in three main questions: how many sellers collect - or do not collect - state sales taxes, what is the revenue loss from noncompliance (at least in those cases where the seller appears to have a sales tax collection obligation), and is noncompliance related to specific factors, especially the characteristics of the sellers? Consider each question.

First, how many sellers collect state sales taxes? Although the number of observations in individual states is sometimes small, our data are nonetheless suggestive. As shown by summary statistics in Table 5, sales taxes are listed in nearly half (or roughly 43 percent) of all of our $\underline{\text { listings. }}$ However, this number overstates seller compliance among individual sellers. Indeed, only 18 percent of all sellers in Table 5 list sales taxes. However, it must be noted that the seller compliance increases sharply with the degree of establishment on eBay, as measured by the seller's rating; see Figure 1. Recall that the eBay rating is at most equal to or less than the number of unique individuals with whom the seller had any completed eBay transactions. Recall also that we define an "Established Seller" on eBay as a seller with rating points of at least 1000; that is, these are sellers who had completed transactions with at least 1000 unique eBay users. This approach enables us to remove "Casual Sellers" (and so smaller sellers) from our data, and to focus only on those sellers who produce a significant volume of transactions. Such sellers are likely to represent medium to large businesses. In separating the casual from the established sellers, we attempt to differentiate between consumer-to-consumer transactions and business-toconsumer transactions. Table 6 provides the state-by-state breakdown of these numbers.

The data in Table 6 show that the average sales tax compliance among all sellers in the electronics category on eBay is quite low, at 18.85 percent. However, when restricted to 
"Established Sellers" only (or eBay sellers with 1000 rating points and above), the compliance rate increases to 43.65 percent, and the average compliance rate for listings is 43.72 percent. $^{17}$

However, although "Established Sellers" have much higher compliance, the variability in the sales tax compliance rate across states is somewhat high. For the sales tax states, the state average sales tax compliance among established sellers is about one-third, with a large standard deviation (15.25). The lowest compliance is observed among Rhode Island sellers, where none of the six sellers in our dataset lists taxes in their listings. South Dakota, Vermont, and Wyoming also exhibit a zero compliance rate. However, the number of established sellers from these states in our dataset is too low to draw any firm conclusions (e.g., 1 each from South Dakota and Vermont and 2 from Wyoming). The highest compliance is in Nebraska, where five out of the seven established sellers in our dataset list the sales tax. The largest state (in terms of the number of sellers) is California, with a nearly 60 percent compliance rate.

Second, what is the revenue loss from noncompliance (where the seller appears to have a sales tax collection obligation)? We compute the revenue losses by state, and report these losses first for the entire population of sellers in our dataset (Table 7) and then for the established sellers only (Table 8 ). Note that for the purpose of revenue computations we only use listings that resulted in a sale. Here we compute the uncollected sales taxes by state, performed for transactions with in-state buyers only, given that the current legal requirement for collection of taxes requires the presence of nexus. On 27 June 2007, in-state transactions constituted only 8 percent of the gross merchandize sales, or $\$ 60,248.86$ out of $\$ 755,904$. However, sellers listed applicable sales taxes for only $\$ 24,464.68$ of these subject to sales taxes on in-state transactions, leading to possible under-collection of $\$ 2,154.97$. These data suggest that for the overall seller population there is a 60 percent under-collection of sales taxes in taxable in-state transactions.

\footnotetext{
${ }^{17}$ Sales taxes were listed in 38.7 percent of sold items and in 47.2 percent of listings that resulted in no sale.
} 
When focusing on "Established Sellers" only, we find that the under-collection of sales taxes declines to 39 percent. $^{18}$

Assuming that the behavior of eBay sellers in the Consumer Electronics category on 27 June 2007 is representative of the typical behavior of sellers on eBay, we can extend the observations from our dataset to the eBay website at large. Table 9 reports our basic computations for each state on the basis of the current quarterly gross merchandise sales of $\$ 10.7$ billion. Using the share of the state's originated sales in our data and the current gross merchandise sales, we compute the expected sales by state. Then, with the help of the in-state sales and sales tax compliance rates observed in our dataset, we compute the expected state's tax liability and the under-collection of sales taxes. It should be emphasized that the computations in Table 9 are merely a rough general guideline as they rely on a static analysis and they assume no change in the buyer behavior in the event of a change in the tax collection by the seller. It should also be remembered that most of our eBay transactions represent business-to-consumer sales, which are meant to be legally taxable.

Perhaps surprisingly, the lack of sales tax compliance by sellers appears to cause only a relatively modest impact on state revenues. The total under-collection is limited to $\$ 30.5$ million per quarter, with California accounting for nearly half of all under-collecting (or \$14.1 million). These small losses are largely due to the size of the cross-border shopping that takes place on eBay, resulting in a very limited volume of in-state transactions. ${ }^{19}$ However, the buyer use tax

\footnotetext{
${ }^{18}$ It is of course possible that some buyers pay the state's use tax on their purchases. However, compliance with use tax is widely believed to be minimal (Due and Mikesell, 1995). See also Note 20.

${ }^{19}$ These losses may be further reduced by state tax holidays, sales tax exemptions of some of the products sold on eBay, exemptions offered by state governments to not for profit sellers, and the like.
} 
liability remains high. Unfortunately for state revenue agencies, use tax compliance is generally low. $^{20}$

When focusing on established sellers we find the revenue losses to be relatively small, given the size of eBay based commerce. Only $\$ 6.9$ million in state sales taxes appears to be undercollected quarterly, with $\$ 11.2$ million in state sales taxes being collected by these sellers on eBay.

Third, what factors affect noncompliance? We use several methods to determine whether noncompliance is related to specific factors. One method examines simple measures of crossborder shopping between the main states in which such border activities are especially important. These fifteen states include: Arizona, California, Florida, Georgia, Illinois, Michigan, Minnesota, New Jersey, New York, Ohio, Pennsylvania, Tennessee, Texas, Virginia and Washington. See Table 10. All of the states listed in Table 10 employ sales taxes. Cross-border shopping is not subject to sales tax collection, but is still subject to use taxes. Our data have no information on use tax compliance by eBay buyers, and so are mainly suggestive. Out of these 15 states, only California is the largest market for its own sellers, and this is mainly due to the large number of buyers and sellers from California. Table 10 underscores both the importance of cross-border shopping on eBay and the shift in the tax compliance from the seller to the buyer.

Another method uses probit estimations to determine how the tax compliance of sellers is affected by their degree of establishment on eBay. Although we do not know which sellers have legal business establishments and which do not, we assume that the volume of seller activity on eBay is directly correlated with their legal establishment as a business. We are mainly interested

\footnotetext{
${ }^{20}$ States recognize the importance of cross-border shopping, and several states list use taxes in income tax return forms. According to Due and Mikesell (1995), states that include use taxes in their resident individual income tax filing include California, Connecticut, Idaho, Indiana, Kentucky, New Jersey, Utah, Vermont, Virginia, and Wisconsin.
} 
in the impact on the dependent variable Taxation of the level of the seller's eBay activity, as measured by two variables: Seller Rating, a measure of the overall transaction based feedback on eBay; and Seller Observations, which is a count of observations by the same seller in our dataset. ${ }^{21}$ We also include several other variables (Seller Rating Percent, Price, Shipping Charges) in some specifications. The definitions of these variables follow their earlier usage. Estimation results are reported in Table 11.

Specification I includes only the seller characteristics. Here we treat each seller as an observation. Our dataset is thus reduced to 6465 observations, the number of unique U.S.-based sellers from states that impose sales taxes only. The results of this estimation show that the Seller Rating, a measure of the seller's past activity on eBay, has a positive and statistically significant effect on the decision to collect sales taxes. Although the coefficient's absolute magnitude is small (0.0000142), its actual impact is quite large, given the difference between the rating levels of the average seller in our dataset (average Seller Rating $=30043$ ) and the new seller. The seller with the average rating in our dataset is 43 percent more likely to collect sales taxes than a seller with a low level of past activity on eBay (who would have a Seller Rating level near zero). This observation suggests that established sellers are significantly more likely to comply with the sales tax regulations. The coefficient on Seller Observations offers further support for this observation.

Interestingly, Seller Rating Percent also has a statistically significant and positive coefficient. This variable is a measure of the positive rating of the seller as a percentage of the overall rating, and it may be interpreted as a measure of honesty of the seller. Our results show

\footnotetext{
${ }^{21}$ Recall that eBay seller rating is based on the number of past transactions on eBay with unique buyers. After each transaction, the buyer has the right to evaluate the seller by assigning the seller a rating point: positive, negative or neutral. The difference between the positive and negative responses constitutes the eBay rating. No matter how many transactions the buyer has had with the seller, each buyer's response counts only once as the rating is uniquely defined with respect to the buyer.
} 
that the more honest the seller is in his or her behavior on eBay, the more likely he or she is to comply with the tax regulations. This observation might suggest that tax compliance is at least in part honesty based.

Specification II is performed on our entire dataset (restricted to listing by U.S. sellers from states with sales taxes). This specification is performed using robust standard errors terminology. The focus on the individual listings as observations enables us to include listing specific variables, such as the Price and the Shipping Charges as controls. The coefficients on the seller establishment measures in Specification II remain positive and statistically significant, supporting the results of Specification I. Price appears to be statistically insignificant, which we believe is largely due to the limited if any tax incidence on the seller due to the significant out of the state(s) of nexus market. Shipping Charges, a variable determined by the seller, has a statistically significant impact at the 95 percent confidence level, which suggests that sellers who collect sales taxes tend to charge marginally higher shipping charges. ${ }^{22}$ Since shipping charges tend to be exempt from sales taxation, this result may suggest a strategic choice on the part of sellers who comply with state sales taxes. These sellers may attempt to shift the cost of their items to the buyer (e. g., from the taxed price to the tax exempt shipping cost) in order to remain competitive with the non-complying sellers. Note that not all listings stated shipping charges, which accounts for the reduced number of observations used in Specification II. ${ }^{23}$

We also estimated specifications to determine whether compliance is affected by, among other things, the level of taxation. We typically find that taxes do not have a statistically significant impact on the probability that the buyer and the seller are from the same state.

\footnotetext{
${ }^{22}$ In most jurisdictions the shipping charges are exempt from sales taxation. By charging higher shipping charges, the seller may shift the cost of the item from the taxable price to the tax exempt shipping charge, in order to reduce the sales tax impact on the buyer.

${ }^{23}$ For a further discussion of the role of shipping charges in eBay auctions, see Melnik and Richardson (2010).
} 
However, we are unable to control for item-specific characteristics in these estimations, so these results seem of little value and are not reported.

\section{CONCLUSIONS}

Using one of the largest transaction datasets collected from the most famous and active online marketplace (eBay), we have attempted to investigate seller compliance with sales taxes. We find that the seller sales tax compliance rate on eBay in the Consumer Electronics category is alarmingly low. When we examine only established sellers, the compliance rate increases significantly, but still to only about one-half of all sellers. Notably, however, since it is those established sellers that account for a disproportionally large amount of online transactions, the low overall seller noncompliance rate causes relatively low losses in sales tax collection. Our analysis of in-state transactions suggests that roughly $\$ 6.9$ million in sales tax revenues is lost quarterly due to the lack of compliance by the established sellers on eBay. This number is not only low in its magnitude compared to the volume of transactions on eBay, but it is also considerably lower than the $\$ 11.2$ million of state sales taxes that are collected quarterly by the established sellers.

A larger threat to the sales tax collection under the current law likely comes from the significant cross-border activity that exists in online market places such as eBay. Nearly 92 percent of transaction activity in our dataset appears to be cross-state commerce; that is, only 8 percent of eBay transactions were instate sales. Coupled with a low level of use tax compliance, this likely presents a much larger threat to state tax revenues than the seller lack of compliance. Indeed, online commerce websites such as eBay provide a convenient and easily accessible venue for cross-border shopping. Consequently, we believe that an increasingly important area of 
concern is use tax compliance. Because our research is limited in its focus to the behavior of the seller, we are unable examine buying behavior. Such analysis is needed in the future in order to understand more fully buyer behavior in online commerce.

\section{ACKNOWLEDGEMENTS}

We are grateful to the editor, George Zodrow, and to three anonymous referees for many helpful comments.

\section{REFERENCES}

Alm, James, and Mikhail I. Melnik, 2005. "Sales Taxes and the Decision to Purchase Online." Public Finance Review 33 (2), 184-212.

Bailey, Joe, Gordon Gao, Wolfgang Jank, Mingfeng Lin, Hank Lucas, and Siva Viswanathan, 2008. "The Long Tail is Longer than You Think: The Surprisingly Large Extent of Online Sales by Small Volume Sellers." The Robert H. Smith School of Business, University of Maryland Working Paper, College Park, MD (available online at: http://ssrn.com/abstract=1132723).

Bruce, Donald, John Deskins, and William F. Fox, 2004. "Has Internet Access Taxation Affected Internet Use? A Panel Data Analysis.” Public Finance Review 32 (2), 131-147.

Bruce, Donald, and William F. Fox, 2000. "E-commerce in the Context of Declining State Sales Tax Bases." National Tax Journal 53 (4, Part 3), 1373-1388.

Bruce, Donald, and William F. Fox, 2001. "E-commerce and Local Finance: Estimates of Direct and Indirect Sales Tax Losses." Municipal Finance Journa/ 22 (3), 24-47.

Bruce, Donald, and William F. Fox, 2004. "State and Local Sales Tax Revenue Losses from ECommerce: Estimates as of July 2004.” State Tax Notes 33 (7) (16 August 2004), 511-518.

Bruce, Donald, William F. Fox, and LeAnn Luna, 2009. "State and Local Government Sales Tax Revenue Losses from Electronic Commerce." Center for Business and Economic Research, University of Tennessee Working Paper, Knoxville, TN.

Bruce, Donald, William F. Fox, and Matthew N. Murray, 2003. "To Tax or Not to Tax: The Case of Electronic Commerce.” Contemporary Economic Policy 21 (1), 25-40.

Cline, Robert J., and Thomas S. Neubig, 1999. The Sky Is Not Falling: Why State and Local Revenues Were Not Significantly Impacted by the Internet in 1998. Ernst and Young, Economics Consulting and Quantitative Analysis, Washington, D.C. 
Cornia, Gary C., David L. Sjoquist, and Larry C. Waters, 2005. "Sales and Use Tax

Simplification and Voluntary Compliance." State Tax Notes 36 (13) (27 June 2005), 989-1009.

Due, John F., and John L. Mikesell, 1995. Sales Taxation - State and Local Structure and Administration. The Urban Institute Press, Washington, D.C.

eBay, 2008. "Fourth Quarter and Full Year 2008 Financial Results" (available online at: http://investor.ebay.com/financial_releases.cfm).

eBay, 2009. "Third Quarter 2009 Financial Results" (available online at:

http://investor.ebay.com/financial_releases.cfm).

Ferris, J. Stephen, 2000. "The Determinants of Cross Border Shopping: Implications for Tax Revenues and Institutional Change." National Tax Journal 53 (4, Part 1), 801-824.

FitzGerald, John D., 1992. "The Distortionary Effects of Taxes on Trade in Border Areas: The Republic of Ireland-UK Border". In Georg Winckler (ed.), Tax Harmonization and Financial Liberalization in Europe, 39-56. St. Martin's Press, New York, NY.

Fox, William F., and LeAnn Luna, 2000. "Should E-Commerce Transactions be Exempt from the Sales Tax?" Quarterly Journal of Electronic Commerce 1 (2), 139-150.

Fox, William F. and LeAnn Luna, and Matthew N. Murray, 2008. "The SSTP and Technology: Implications for the Future of the Sales Tax." National Tax Journal 61 (4 Part 2), 823-841.

Fox, William F., and Matthew N. Murray, 1997. "The Sales Tax and Electronic Commerce: So What's New?" National Tax Journal 50 (3), 573-592.

Garrett, Thomas A., and Thomas L. Marsh, 2002. "The Revenue Impacts of Cross-Border Lottery Shopping in the Presence of Spatial Autocorrelation." Regional Science and Urban Economics 32 (4), 501-519.

Goolsbee, Austan, 2000. "In a World without Borders: The Impact of Taxes on Internet Commerce." Quarterly Journal of Economics 115 (2), 561-576.

Goolsbee, Austan, and Jonathan Zittrain, 1999. "Evaluating the Costs and Benefits of Taxing Internet Commerce." National Tax Journal 52 (3), 413-428.

Gordon, Roger H., and Soren Bo Nielson, 1997. "Tax Evasion in an Open Economy: Valueadded vs. Income Taxation.” Journal of Public Economics 66 (2), 173-197.

Johnson, Peter A., 2003. "A Current Calculation of Uncollected Sales Tax Arising from Internet Growth." The Direct Marketing Association, New York, NY. 
Johnson, Peter A., 2008. "Setting the Record Straight: The Modest Effect of E-commerce on State and Local Sales Tax Collections.” The Direct Marketing Association, New York, NY.

McQuivey, James L., and Gillian DeMaulin, 2000. "States Lose Half a Billion in Taxes to Web Retail.” Technographics Brief, Forrester Research, Inc., Cambridge, MA.

Melnik, Mikhail I., and James Alm, 2002. "Does a Seller's E-commerce Reputation Matter? Evidence from eBay Auctions." The Journal of Industrial Economics 50 (3), 337-350.

Melnik, Mikhail I., and Paul Richardson, 2010. "The Impact of Shipping Charges in Online Auctions: Evidence From Electronics Auctions on eBay." The BRC Academy Journal of Business 1 (1), 81-106.

Scanlan, Mark A., 2007. “Tax Sensitivity in Electronic Commerce.” Fiscal Studies 28 (4), $417-$ 436.

United States General Accounting Office, 2000. Sales Taxes: Electronic Commerce Growth Presents Challenges: Revenues Losses Are Uncertain. GAO/GGD/OCE-00-165, Washington, D.C.

United States Census Bureau, 2009. E-Stats. Washington, D.C. (available online at: http://www.census.gov/econ/estats/2007/2007reportfinal.pdf).

United States Census Bureau, 2009. Quarterly Retail E-commerce Sales Report. Washington, D.C. (available online at: http://www.census.gov/mrts/www/data/html/09Q1.html). 
Table 1 Major Categories of Products Listed on eBay, 27 July 2007

\begin{tabular}{lcc}
\hline & \multicolumn{2}{c}{ Number of Listings } \\
\cline { 2 - 3 } Category & All Listings & U.S. Listings Only \\
\hline Antiques & 26,216 & 14,041 \\
Art & 25,163 & 16,729 \\
Baby & 8,383 & 6,797 \\
Books & 69,665 & 53,081 \\
Business \& Industrial & 47,150 & 36,337 \\
Cameras \& Photo & 46,877 & 32,754 \\
Cell Phones \& PDAs & 95,146 & 83,891 \\
Clothing, Shoes \& Accessories & 305,163 & 221,096 \\
Coins \& Paper Money & 38,376 & 24,469 \\
Collectibles & 225,085 & 145,055 \\
Computers \& Networking & 84,113 & 64,977 \\
Consumer Electronics & 91,903 & 71,165 \\
Crafts & 38,850 & 30,239 \\
Dolls \& Bears & 18,493 & 13,228 \\
DVDs \& Movies & 52,140 & 43,506 \\
Entertainment Memorabilia & 25,010 & 18,270 \\
eBay Motors & $1,121,605$ & $1,121,411$ \\
Gift Certificates & 2,756 & 2,605 \\
Health \& Beauty & 54,836 & 44,340 \\
Home \& Garden & 106,380 & 79,905 \\
Jewelry \& Watches & 168,311 & 111,530 \\
Music & 44,358 & 29,827 \\
Musical Instruments & 27,551 & 19,764 \\
Pottery \& Glass & 30,478 & 19,562 \\
Real Estate & 317 & 271 \\
Specialty Services & 1,195 & 1,013 \\
Sporting Goods & 82,205 & 60,761 \\
Sports Memorabilia, Cards \& Fan Shop & 117,880 & 78,585 \\
Stamps & 19,660 & 9,193 \\
Tickets & 8,274 & 6,062 \\
Toys \& Hobbies & 107,400 & 72,729 \\
Travel & 1,611 & 1,418 \\
Video Games & 69,871 & 59,654 \\
Everything Else & 29,706 & 22,700 \\
\hline Total & $3,192,127$ & $2,616,965$ \\
\hline & & \\
& & \\
& &
\end{tabular}


Table 2

Consumer Electronic Category Daily Activity, U.S. Listings Only

\begin{tabular}{|c|c|c|c|c|c|c|c|c|}
\hline \multirow[b]{2}{*}{ Category } & \multicolumn{3}{|c|}{6 January 2007} & \multicolumn{3}{|c|}{7 January 2008} & \multicolumn{2}{|c|}{27 July 2007} \\
\hline & $\begin{array}{c}\text { Number } \\
\text { of } \\
\text { Listings }\end{array}$ & $\begin{array}{c}\text { Percent of } \\
\text { Consumer } \\
\text { Electronics } \\
\text { Category }\end{array}$ & $\begin{array}{c}\text { Percent of } \\
\text { Obtained } \\
\text { Categories }\end{array}$ & $\begin{array}{c}\text { Number } \\
\text { of } \\
\text { Listings }\end{array}$ & $\begin{array}{c}\text { Percent of } \\
\text { Consumer } \\
\text { Electronics } \\
\text { Category }\end{array}$ & $\begin{array}{c}\text { Percent of } \\
\text { Obtained } \\
\text { Categories }\end{array}$ & $\begin{array}{c}\text { Number } \\
\text { of } \\
\text { Listings }\end{array}$ & $\begin{array}{c}\text { Percent of } \\
\text { Obtained } \\
\text { Categories }\end{array}$ \\
\hline Apple iPod, MP3 Players & 5750 & 8.08 & 18.57 & 5583 & 8.11 & 18.82 & 3587 & 16.08 \\
\hline A/V Accessories \& Cables & 9979 & 14.02 & 32.22 & 9776 & 14.19 & 32.95 & 5623 & 25.21 \\
\hline Batteries \& Chargers & 865 & 1.22 & 2.79 & 759 & 1.10 & 2.56 & 267 & 1.20 \\
\hline Car Electronics & 5329 & 7.49 & & 4279 & 6.21 & & & \\
\hline DVD \& Home Theater & 1692 & 2.38 & 5.46 & 1572 & 2.28 & 5.30 & 1756 & 7.87 \\
\hline Gadgets \& Other Electronics & 3713 & 5.22 & 11.99 & 3443 & 5.00 & 11.60 & 2203 & 9.88 \\
\hline GPS Devices & 3165 & 4.45 & & 3142 & 4.56 & & & \\
\hline Home Audio & 2405 & 3.38 & 7.77 & 2279 & 3.31 & 7.68 & 2390 & 10.72 \\
\hline MP3 Accessories & 28952 & 40.68 & & 29169 & 42.35 & & & \\
\hline Portable Audio/Video & 1222 & 1.72 & 3.95 & 1249 & 1.81 & 4.21 & 733 & 3.29 \\
\hline Radios: CB, Ham \& Shortwave & 1851 & 2.60 & 5.98 & 1845 & 2.68 & 6.22 & 1766 & 7.92 \\
\hline Satellite Radio & 811 & 1.14 & 2.62 & 761 & 1.10 & 2.56 & 712 & 3.19 \\
\hline Satellite, Cable TV & 1534 & 2.16 & 4.95 & 1446 & 2.10 & 4.87 & 1252 & 5.61 \\
\hline Telephones \& Pagers & 1149 & 1.61 & 3.71 & 959 & 1.39 & 3.23 & 692 & 3.10 \\
\hline Televisions & 1366 & 1.92 & & 1214 & 1.76 & & & \\
\hline Vintage Electronics & 1186 & 1.67 & & 1221 & 1.77 & & & \\
\hline Wholesale Lots & 196 & 0.28 & & 177 & 0.26 & & & \\
\hline Consumer Electronics & 71165 & 100 & & 68874 & 100 & & & \\
\hline $\begin{array}{l}\text { Totals for the Relevant Categories } \\
\text { obtained on } 27 \text { July } 2007\end{array}$ & 30971 & 43.52 & & 29672 & 43.08 & & 20981 & \\
\hline
\end{tabular}

\section{Table 3}

Listings by Subcategories, 27 July 2007

\begin{tabular}{|c|c|c|c|c|c|c|c|}
\hline Category & Observations ${ }^{\mathrm{a}}$ & $\begin{array}{c}\text { Transactions } \\
\text { (Number) }\end{array}$ & $\begin{array}{c}\text { Transactions } \\
(\%)\end{array}$ & $\begin{array}{c}\text { Transactions } \\
(\$)\end{array}$ & $\begin{array}{l}\text { Average } \\
\text { Price }(\$)\end{array}$ & $\begin{array}{l}\text { Standard } \\
\text { Deviation of } \\
\text { Price }(\$)\end{array}$ & $\begin{array}{c}\text { Price Range } \\
\text { (sold items only) ( } \$\end{array}$ \\
\hline Apple iPod, MP3 Players & 3905 & 2404 & 61.55 & 237783.45 & 98.931 & 80.904 & $0.01-1279.96$ \\
\hline A/V Accessories \& Cables & 6114 & 2038 & 33.33 & 55134.35 & 27.052 & 58.002 & $0.01-760.00$ \\
\hline Batteries \& Chargers & 271 & 81 & 29.78 & 1584.05 & 19.641 & 46.170 & $0.01-407.77$ \\
\hline DVD \& Home Theater & 1797 & 898 & 49.98 & 119533.26 & 133.098 & 177.154 & $0.99-999.00$ \\
\hline Gadgets \& Other Electronics & 2219 & 975 & 43.93 & 54970.28 & 56.394 & 85.894 & $0.01-910.00$ \\
\hline Home Audio & 2642 & 1319 & 49.93 & 153729.61 & 116.528 & 155.025 & $0.01-999.00$ \\
\hline Portable Audio/Video & 749 & 396 & 52.91 & 18399.28 & 46.431 & 55.874 & $0.01-480.00$ \\
\hline Radios: CB, Ham,Shortwave & 1852 & 927 & 50.05 & 62761.94 & 67.707 & 108.241 & $0.01-950.00$ \\
\hline Satellite Radio & 738 & 340 & 46.01 & 9803.96 & 28.876 & 32.066 & $0.01-233.89$ \\
\hline Satellite, Cable TV & 1248 & 501 & 40.12 & 27474.62 & 54.860 & 96.551 & $0.01-986.99$ \\
\hline Telephones \& Pagers & 916 & 441 & 48.15 & 14730.05 & 33.396 & 53.549 & $0.01-849.00$ \\
\hline Total & 22451 & 10319 & 45.96 & 755904.86 & --- & --- & --- \\
\hline
\end{tabular}

a "Observation" is defined as a transaction or a listing that results in no sales. Thus, every single item listing produces one data observation, while a multi-item listing with (say) three unique buyers will produce three observations. 
Table 4

Descriptive Statistics I

\begin{tabular}{lcc}
\hline & Observations $^{\mathbf{a}}$ & Listings $^{\quad \text { Total }}$ \\
\hline & 22451 & 20831 \\
US Sellers only (state known) & 22239 & 20625 \\
US Sellers only (state unknown) & 65 & 65 \\
Seller Location Unknown & 39 & 37 \\
Canadian Sellers & 70 & 69 \\
Puerto Rico & 6 & 6 \\
Rest of the World & 33 & 30 \\
\hline
\end{tabular}

\section{Sellers}

Total

6888

US Sellers (state known)

6791

US Sellers (state unknown)

33

US Sellers from states with sales taxes

6596

Sellers (Puerto Rico)

Sellers (outside US and Puerto Rico)

28

Sellers (location unknown)

31

Total

$$
\text { Buyers }
$$

US Buyers (state of residence known)

US Buyers (state of residence unknown)

Canadian Buyers

Puerto Rico

Rest of the World

Buyer (location kept private or unknown)

a "Observation" is defined as a transaction or a listing that results in no sales. Thus, every single item listing produces one data observation, while a multi-item listing with (say) three unique buyers will produce three observations.

Table 5

Descriptive Statistics II

\begin{tabular}{lcccc}
\hline & Average & Standard Deviation & Minimum & Maximum \\
\hline Price(all listings) & 64.713 & 111.575 & 0.01 & 1279.96 \\
Price (sold items only) & 73.026 & 108.277 & 0.01 & 1279.96 \\
Sold & 0.460 & & 0 & 1 \\
Observations per seller & 36.775 & 60.183 & 1 & 306 \\
Seller rating (average based on number of listings) & 29784.21 & 93327.91 & -1 & 590696 \\
Seller rating (average based on number of sellers) & 3489.09 & 3155.296 & -1 & 590696 \\
Taxation (average based on number of listings) & 0.431 & & 0 & 1 \\
Taxation (average based on number of sellers) & 0.177 & & 0 & 1 \\
Taxation (average based on number of listings, & & & 0 & 1 \\
states requiring sales taxes only) & 0.446 & & & \\
Taxation (averaged base on number of sellers, & & & 0 & 1 \\
states requiring sales taxes only) & 0.183 & & & \\
\hline
\end{tabular}

a "Observation" is defined as a transaction or a listing that results in no sales. Thus, every single item listing produces one data observation, while a multi-item listing with (say) three unique buyers will produce three observations. 
Table 6

Buyer/Seller Activity by State

\begin{tabular}{|c|c|c|c|c|c|c|c|c|c|c|c|}
\hline \multirow[b]{2}{*}{ State } & \multirow[b]{2}{*}{ Buyers } & \multicolumn{3}{|c|}{ All Sellers } & \multicolumn{3}{|c|}{ Established Sellers } & \multicolumn{3}{|c|}{ Listings } & \multirow[b]{2}{*}{ Observations } \\
\hline & & Total & $\begin{array}{l}\text { Listed } \\
\text { Tax }\end{array}$ & $\begin{array}{c}\text { Listed } \\
\text { Tax/Tota } \\
\text { I (\%) }\end{array}$ & Total & $\begin{array}{l}\text { Listed } \\
\text { Tax }\end{array}$ & $\begin{array}{c}\text { Listed } \\
\text { Tax/Tota } \\
\text { I (\%) }\end{array}$ & Total & $\begin{array}{l}\text { Listed } \\
\text { Tax }\end{array}$ & $\begin{array}{c}\text { Listed } \\
\text { Tax/Tota } \\
\text { I (\%) }\end{array}$ & \\
\hline ALABAMA & 96 & 57 & 3 & 5.26 & 15 & 2 & 13.33 & 79 & 3 & 3.80 & 95 \\
\hline ALASKA & 16 & 12 & N/A & N/A & 3 & N/A & N/A & 16 & N/A & N/A & 16 \\
\hline ARIZONA & 173 & 179 & 30 & 16.76 & 63 & 22 & 34.92 & 726 & 120 & 16.53 & 799 \\
\hline ARKANSAS & 50 & 51 & 5 & 9.80 & 19 & 5 & 26.32 & 80 & 14 & 17.50 & 85 \\
\hline CALIFORNIA & 1024 & 1132 & 353 & 31.18 & 436 & 260 & 59.63 & 5523 & 3793 & 68.68 & 5950 \\
\hline COLORADO & 125 & 98 & 14 & 14.29 & 32 & 8 & 25.00 & 164 & 23 & 14.02 & 169 \\
\hline CONNECTICUT & 99 & 71 & 10 & 14.08 & 23 & 9 & 39.13 & 102 & 17 & 16.67 & 107 \\
\hline DELAWARE & 33 & 18 & N/A & $\mathrm{N} / \mathrm{A}$ & 9 & $\mathrm{~N} / \mathrm{A}$ & $\mathrm{N} / \mathrm{A}$ & 40 & N/A & $\mathrm{N} / \mathrm{A}$ & 43 \\
\hline DISTRICT OF COLUMBIA & 12 & 6 & 1 & 16.67 & 2 & 1 & 50.00 & 198 & 1 & 0.51 & 206 \\
\hline FLORIDA & 574 & 544 & 120 & 22.06 & 165 & 78 & 47.27 & 1739 & 634 & 36.46 & 1829 \\
\hline GEORGIA & 224 & 200 & 27 & 13.50 & 50 & 19 & 38.00 & 450 & 67 & 14.89 & 480 \\
\hline HAWAII & 28 & 14 & 2 & 14.29 & 4 & 2 & 50.00 & 20 & 6 & 30.00 & 20 \\
\hline IDAHO & 40 & 25 & 6 & 24.00 & 9 & 5 & 55.56 & 77 & 46 & 59.74 & 79 \\
\hline ILLINOIS & 380 & 344 & 62 & 18.02 & 95 & 42 & 44.21 & 957 & 448 & 46.81 & 1052 \\
\hline INDIANA & 147 & 152 & 25 & 16.45 & 42 & 18 & 42.86 & 375 & 135 & 36.00 & 412 \\
\hline IOWA & 71 & 53 & 4 & 7.55 & 13 & 3 & 23.08 & 233 & 6 & 2.58 & 244 \\
\hline KANSAS & 79 & 61 & 11 & 18.03 & 22 & 8 & 36.36 & 147 & 29 & 19.73 & 157 \\
\hline KENTUCKY & 102 & 78 & 7 & 8.97 & 14 & 4 & 28.57 & 137 & 38 & 27.74 & 151 \\
\hline LOUISIANA & 84 & 38 & 4 & 10.53 & 7 & 2 & 28.57 & 61 & 16 & 26.23 & 69 \\
\hline MAINE & 32 & 33 & 1 & 3.03 & 6 & 1 & 16.67 & 45 & 1 & 2.22 & 47 \\
\hline MARYLAND & 153 & 119 & 25 & 21.01 & 31 & 14 & 45.16 & 214 & 71 & 33.18 & 224 \\
\hline MASSACHUSETTS & 153 & 122 & 14 & 11.48 & 28 & 8 & 28.57 & 182 & 42 & 23.08 & 189 \\
\hline MICHIGAN & 267 & 232 & 33 & 14.22 & 49 & 19 & 38.78 & 522 & 144 & 27.59 & 537 \\
\hline MINNESOTA & 134 & 115 & 26 & 22.61 & 44 & 21 & 47.73 & 259 & 118 & 45.56 & 266 \\
\hline MISSISSIPPI & 45 & 27 & 2 & 7.41 & 5 & 2 & 40.00 & 35 & 7 & 20.00 & 35 \\
\hline MISSOURI & 117 & 114 & 15 & 13.16 & 27 & 10 & 37.04 & 264 & 118 & 44.70 & 270 \\
\hline MONTANA & 25 & 13 & N/A & $\mathrm{N} / \mathrm{A}$ & 4 & N/A & N/A & 24 & N/A & N/A & 24 \\
\hline NEBRASKA & 35 & 33 & 9 & 27.27 & 7 & 5 & 71.43 & 95 & 62 & 65.26 & 102 \\
\hline NEVADA & 61 & 64 & 8 & 12.50 & 21 & 7 & 33.33 & 122 & 10 & 8.20 & 130 \\
\hline NEW HAMPSHIRE & 36 & 46 & N/A & N/A & 12 & $\mathrm{~N} / \mathrm{A}$ & N/A & 106 & N/A & N/A & 108 \\
\hline NEW JERSEY & 254 & 218 & 34 & 15.60 & 64 & 26 & 40.63 & 658 & 249 & 37.84 & 705 \\
\hline NEW MEXICO & 47 & 28 & 3 & 10.71 & 6 & 2 & 33.33 & 61 & 9 & 14.75 & 62 \\
\hline NEW YORK & 550 & 523 & 102 & 19.50 & 177 & 78 & 44.07 & 1765 & 862 & 48.84 & 2009 \\
\hline NORTH CAROLINA & 229 & 164 & 22 & 13.41 & 41 & 15 & 36.59 & 322 & 61 & 18.94 & 336 \\
\hline NORTH DAKOTA & 15 & 6 & 1 & 16.67 & 3 & 1 & 33.33 & 6 & 1 & 16.67 & 6 \\
\hline OHIO & 299 & 251 & 41 & 16.33 & 89 & 33 & 37.08 & 539 & 169 & 31.35 & 564 \\
\hline OKLAHOMA & 87 & 58 & 6 & 10.34 & 20 & 4 & 20.00 & 151 & 65 & 43.05 & 167 \\
\hline OREGON & 111 & 108 & N/A & N/A & 36 & N/A & N/A & 287 & 5 & 1.74 & 313 \\
\hline PENNSYLVANIA & 354 & 270 & 41 & 15.19 & 68 & 32 & 47.06 & 616 & 180 & 29.22 & 634 \\
\hline RHODE ISLAND & 19 & 25 & 2 & 8.00 & 6 & 0 & 0.00 & 31 & 2 & 6.45 & 33 \\
\hline SOUTH CAROLINA & 90 & 65 & 7 & 10.77 & 17 & 4 & 23.53 & 104 & 15 & 14.42 & 104 \\
\hline SOUTH DAKOTA & 18 & 11 & 1 & 9.09 & 1 & 0 & 0.00 & 16 & 1 & 6.25 & 16 \\
\hline TENNESSEE & 188 & 123 & 27 & 21.95 & 50 & 22 & 44.00 & 525 & 313 & 59.62 & 572 \\
\hline TEXAS & 572 & 414 & 77 & 18.60 & 125 & 52 & 41.60 & 1435 & 549 & 38.26 & 1622 \\
\hline UTAH & 81 & 70 & 16 & 22.86 & 28 & 11 & 39.29 & 191 & 77 & 40.31 & 212 \\
\hline VERMONT & 17 & 10 & 0 & 0.00 & 1 & 0 & 0.00 & 15 & 0 & 0.00 & 15 \\
\hline VIRGINIA & 219 & 127 & 14 & 11.02 & 27 & 6 & 22.22 & 285 & 88 & 30.88 & 299 \\
\hline WASHINGTON & 207 & 152 & 25 & 16.45 & 45 & 17 & 37.78 & 391 & 176 & 45.01 & 420 \\
\hline WEST VIRGINIA & 30 & 25 & 4 & 16.00 & 6 & 2 & 33.33 & 55 & 11 & 20.00 & 63 \\
\hline WISCONSIN & 140 & 109 & 7 & 6.42 & 20 & 4 & 20.00 & 179 & 15 & 8.38 & 187 \\
\hline WYOMING & 13 & 4 & 0 & 0.00 & 2 & 0 & 0.00 & 4 & 0 & 0.00 & 4 \\
\hline State Unknown & 424 & 33 & 4 & 12.12 & 6 & 2 & 33.33 & 65 & 22 & 33.85 & 65 \\
\hline Total (Sales Tax States) & 7734 & 6615 & 1247 & 18.85 & 2025 & 884 & 43.65 & 20155 & 8812 & 43.72 & 21734 \\
\hline Canada & 408 & 12 & 2 & & 9 & 1 & & 65 & 4 & & 70 \\
\hline Puerto Rico & 51 & 5 & & & & & & 6 & & & 6 \\
\hline Rest of the World & 353 & 16 & 0 & & 7 & 0 & & 30 & 0 & & 33 \\
\hline Location Unknown & 70 & 31 & 0 & & 9 & 0 & & 37 & 0 & & 39 \\
\hline Total & 9261 & 6909 & 1253 & 18.14 & 2120 & 887 & 41.84 & 20831 & 8838 & 42.43 & 22451 \\
\hline
\end{tabular}

a "Observation" is defined as a transaction or a listing that results in no sales. Thus, every single item listing produces one data observation, while a multi-item listing with (say) three unique buyers will produce three observations. 


\section{Table 7}

Volume of Transactions, All Sellers

\begin{tabular}{|c|c|c|c|c|c|c|}
\hline State & $\begin{array}{c}\text { Value of All } \\
\text { Transactions } \\
(\$)\end{array}$ & $\begin{array}{l}\text { Value of } \\
\text { Instate } \\
\text { Transactions } \\
\text { (\$) }\end{array}$ & $\begin{array}{c}\text { Value of } \\
\text { Instate } \\
\text { Transactions } \\
\text { Where Tax } \\
\text { Was Listed } \\
(\$)\end{array}$ & $\begin{array}{c}\text { State } \\
\text { Sales } \\
\text { Tax Rate } \\
(\%)\end{array}$ & $\begin{array}{c}\text { State } \\
\text { Sales Tax } \\
\text { Collected } \\
(\$)\end{array}$ & $\begin{array}{c}\text { State Sales Tax } \\
\text { Uncollected by } \\
\text { Seller }(\$)\end{array}$ \\
\hline ALABAMA & 2752.64 & 5 & 0 & 4 & 0 & 0.2 \\
\hline ALASKA & 2190.48 & 0 & NA & None & NA & NA \\
\hline ARIZONA & 18927.73 & 272.96 & 66.99 & 5.6 & 3.75 & 11.53 \\
\hline ARKANSAS & 2623.58 & 43.95 & 0 & 6 & 0 & 2.64 \\
\hline CALIFORNIA & 123735.77 & 20080.28 & 6313.65 & 7.25 & 457.74 & 998.08 \\
\hline COLORADO & 7915.36 & 9.99 & 9.99 & 2.9 & 0.29 & 0 \\
\hline CONNECTICUT & 6189.07 & 56.26 & 0 & 6 & 0 & 3.38 \\
\hline DELAWARE & 1145.62 & 156.96 & NA & None & NA & NA \\
\hline DISTRICT OF COLUMBIA & 814.23 & 0 & 0 & 5.75 & 0 & 0 \\
\hline FLORIDA & 46670.67 & 4778.19 & 987.79 & 6 & 59.27 & 227.42 \\
\hline GEORGIA & 19898.06 & 845.52 & 404.88 & 4 & 16.2 & 17.63 \\
\hline HAWAII & 1430.89 & 843.99 & 8.99 & 4 & 0.36 & 33.4 \\
\hline IDAHO & 1669.58 & 0 & 0 & 6 & 0 & 0 \\
\hline ILLINOIS & 41214.46 & 1802.54 & 671.42 & 6.25 & 41.96 & 70.7 \\
\hline INDIANA & 13106.65 & 341.1 & 170.95 & 6 & 10.26 & 10.21 \\
\hline IOWA & 3458.08 & 0.99 & 0 & 5 & 0 & 0.05 \\
\hline KANSAS & 11382.84 & 0 & 0 & 5.3 & 0 & 0 \\
\hline KENTUCKY & 4742.41 & 370 & 0 & 6 & 0 & 22.2 \\
\hline LOUISIANA & 3164.32 & 7.99 & 0 & 4 & 0 & 0.32 \\
\hline MAINE & 2015.43 & 0 & 0 & 5 & 0 & 0 \\
\hline MARYLAND & 14687.53 & 873.51 & 0 & 5 & 0 & 43.68 \\
\hline MASSACHUSETTS & 10076.19 & 0 & 0 & 5 & 0 & 0 \\
\hline MICHIGAN & 15640.67 & 216.18 & 9.98 & 6 & 0.6 & 12.37 \\
\hline MINNESOTA & 15098.54 & 1430.99 & 869.99 & 6.5 & 56.55 & 36.47 \\
\hline MISSISSIPPI & 1006.74 & 0 & 0 & 7 & 0 & 0 \\
\hline MISSOURI & 9114.69 & 5 & 0 & 4.225 & 0 & 0.21 \\
\hline MONTANA & 500.74 & 0 & NA & None & NA & NA \\
\hline NEBRASKA & 3957.86 & 0 & 0 & 5.5 & 0 & 0 \\
\hline NEVADA & 3550.97 & 119.46 & 30.49 & 6.5 & 1.98 & 5.78 \\
\hline NEW HAMPSHIRE & 7189.65 & 5 & NA & None & NA & NA \\
\hline NEW JERSEY & 25433.7 & 1862.48 & 391.99 & 7 & 27.44 & 102.93 \\
\hline NEW MEXICO & 2120.42 & 0 & 0 & 5 & 0 & 0 \\
\hline NEW YORK & 73604.56 & 4903.08 & 2523.67 & 4 & 100.95 & 95.18 \\
\hline NORTH CAROLINA & 14514.56 & 435.01 & 299.99 & 4.25 & 12.75 & 5.74 \\
\hline NORTH DAKOTA & 88.94 & 0 & 0 & 5 & 0 & 0 \\
\hline $\mathrm{OHIO}$ & 21895.67 & 763.31 & 28.49 & 5.5 & 1.57 & 40.42 \\
\hline OKLAHOMA & 5835.76 & 41 & 0 & 4.5 & 0 & 1.85 \\
\hline OREGON & 9447.09 & 502.99 & NA & None & NA & NA \\
\hline PENNSYLVANIA & 31199.53 & 1573.38 & 379 & 6 & 22.74 & 71.66 \\
\hline RHODE ISLAND & 2066.48 & 40 & 40 & 7 & 2.8 & 0 \\
\hline SOUTH CAROLINA & 5330.342 & 30.02 & 0 & 5 & 0 & 1.5 \\
\hline SOUTH DAKOTA & 631.43 & 0 & 0 & 4 & 0 & 0 \\
\hline TENNESSEE & 27119.86 & 378.84 & 250.95 & 7 & 17.57 & 8.95 \\
\hline TEXAS & 58784.27 & 4311.87 & 1497.77 & 6.25 & 93.61 & 175.88 \\
\hline UTAH & 6190.93 & 116.49 & 16.5 & 4.75 & 0.78 & 4.75 \\
\hline VERMONT & 582.49 & 0 & 0 & 6 & 0 & 0 \\
\hline VIRGINIA & 19612.22 & 616.97 & 387 & 5 & 19.35 & 11.5 \\
\hline WASHINGTON & 30962.92 & 1844.51 & 173.01 & 6.5 & 11.25 & 108.65 \\
\hline WEST VIRGINIA & 1801.07 & 7.56 & 0 & 6 & 0 & 0.45 \\
\hline WISCONSIN & 10638.83 & 584.75 & 0 & 5 & 0 & 29.24 \\
\hline WYOMING & 19.99 & 0 & 0 & 4 & 0 & 0 \\
\hline State Unknown & 2181.51 & & & & & \\
\hline Taxable in All States* & 9970.84 & 9970.84 & 8931.19 & 5.92 & 528.44 & 0 \\
\hline Total & 755904.86 & 60248.96 & 24464.68 & --- & 1488.21 & 2154.97 \\
\hline
\end{tabular}


Table 8

Volume of Transactions, Established Sellers Only

\begin{tabular}{|c|c|c|c|c|c|c|}
\hline State & $\begin{array}{c}\text { Value of All } \\
\text { Transactions } \\
(\$)\end{array}$ & $\begin{array}{c}\text { Value of } \\
\text { Instate } \\
\text { Transactions } \\
\text { (\$) }\end{array}$ & $\begin{array}{c}\text { Value of } \\
\text { Instate } \\
\text { Transactions } \\
\text { Where Tax } \\
\text { Was listed (\$) }\end{array}$ & $\begin{array}{c}\text { State } \\
\text { Sales Tax } \\
\text { Rate (\%) }\end{array}$ & $\begin{array}{c}\text { State Sales } \\
\text { Tax } \\
\text { Collected } \\
(\$)\end{array}$ & $\begin{array}{c}\text { State Sales Tax } \\
\text { Uncollected by } \\
\text { Seller }(\$)\end{array}$ \\
\hline ALABAMA & 497.5 & 5 & 0 & 4 & 0 & 0.2 \\
\hline ALASKA & 169.49 & 0 & 0 & NA & None & None \\
\hline ARIZONA & 10156.01 & 135.96 & 66.99 & 5.6 & 3.75 & 3.86 \\
\hline ARKANSAS & 801.86 & 43.95 & 0 & 6 & 0 & 2.64 \\
\hline CALIFORNIA & 56362.75 & 7873.24 & 5300.69 & 7.25 & 384.30 & 186.51 \\
\hline COLORADO & 3990.19 & 9.99 & 9.99 & 2.9 & 0.29 & 0 \\
\hline CONNECTICUT & 2856.48 & 12.26 & 0 & 6 & 0 & 0.74 \\
\hline DELAWARE & 368.7 & 0 & 0 & NA & None & None \\
\hline DISTRICT OF COLUMBIA & 404.3 & 0 & 0 & 5.75 & 0 & 0 \\
\hline FLORIDA & 16952.81 & 923.39 & 267.83 & 6 & 16.07 & 39.33 \\
\hline GEORGIA & 9125.67 & 409.87 & 404.88 & 4 & 16.20 & 0.20 \\
\hline HAWAII & 64 & 8.99 & 8.99 & 4 & 0.36 & 0 \\
\hline IDAHO & 456.89 & 0 & 0 & 6 & 0 & 0 \\
\hline ILLINOIS & 12736.15 & 698.31 & 438.93 & 6.25 & 27.43 & 16.21 \\
\hline INDIANA & 4743.97 & 148.94 & 89.95 & 6 & 5.40 & 3.54 \\
\hline IOWA & 615.53 & 0 & 0 & 5 & 0 & 0 \\
\hline KANSAS & 1423.12 & 0 & 0 & 6 & 0 & 0 \\
\hline KENTUCKY & 1161 & 0 & 0 & 6 & 0 & 0 \\
\hline LOUISIANA & 493.94 & 0 & 0 & 4 & 0 & 0 \\
\hline MAINE & 757.55 & 0 & 0 & 5 & 0 & 0 \\
\hline MARYLAND & 2049.25 & 0 & 0 & 5 & 0 & 0 \\
\hline MASSACHUSETTS & 1710.27 & 0 & 0 & 5 & 0 & 0 \\
\hline MICHIGAN & 2238.87 & 23.93 & 9.98 & 6 & 0.60 & 0.84 \\
\hline MINNESOTA & 6632.11 & 869.99 & 869.99 & 6.5 & 56.55 & 0 \\
\hline MISSISSIPPI & 80.29 & 0 & 0 & 7 & 0 & 0 \\
\hline MISSOURI & 3042.41 & 0 & 0 & 4.225 & 0 & 0 \\
\hline MONTANA & 48.5 & 0 & 0 & NA & None & None \\
\hline NEBRASKA & 2129.36 & 0 & 0 & 5.5 & 0 & 0 \\
\hline NEVADA & 1336.89 & 5.99 & 5.99 & 6.5 & 0.39 & 0 \\
\hline NEW HAMPSHIRE & 1331 & 5 & 0 & $\mathrm{~N} / \mathrm{A}$ & None & None \\
\hline NEW JERSEY & 11310.58 & 1487.43 & 391.99 & 7 & 27.44 & 76.68 \\
\hline NEW MEXICO & 350.5 & 0 & 0 & 5 & 0 & 0 \\
\hline NEW YORK & 45719.44 & 2721.48 & 2413.25 & 4 & 96.53 & 12.33 \\
\hline NORTH CAROLINA & 7456.72 & 351.02 & 299.99 & 4.25 & 12.75 & 2.17 \\
\hline NORTH DAKOTA & 88.94 & 0 & 0 & 5 & 0 & 0 \\
\hline OHIO & 10013.29 & 656.36 & 28.49 & 5.5 & 1.57 & 34.53 \\
\hline OKLAHOMA & 2454.05 & 0 & 0 & 4.5 & 0 & 0 \\
\hline OREGON & 1658.56 & 502.99 & 0 & N/A & None & None \\
\hline PENNSYLVANIA & 16555.16 & 180.99 & 179 & 6 & 10.74 & 0.12 \\
\hline RHODE ISLAND & 844.07 & 0 & 0 & 7 & 0 & 0 \\
\hline SOUTH CAROLINA & 212.46 & 0 & 0 & 5 & 0 & 0 \\
\hline SOUTH DAKOTA & 10.5 & 0 & 0 & 4 & 0 & 0 \\
\hline TENNESSEE & 20759.17 & 265.33 & 250.95 & 7 & 17.57 & 1.01 \\
\hline TEXAS & 29355.6 & 1484.85 & 1347.41 & 6.25 & 84.21 & 8.59 \\
\hline UTAH & 2966.02 & 16.5 & 16.5 & 4.75 & 0.78 & 0 \\
\hline VERMONT & 0 & 0 & 0 & 4.75 & 0 & 0 \\
\hline VIRGINIA & 7512 & 411.99 & 387 & 5 & 19.35 & 1.25 \\
\hline WASHINGTON & 21042.3 & 1702.55 & 173.01 & 6.5 & 11.25 & 99.42 \\
\hline WEST VIRGINIA & 28.44 & 7.56 & 0 & 6 & 0 & 0 \\
\hline WISCONSIN & 2070.3 & 0 & 0 & 5 & 0 & 0 \\
\hline WYOMING & 19 & 0 & 0 & 4 & 0 & 0 \\
\hline Total & 325163.96 & 20963.86 & 12961.8 & & 793.52 & 490.16 \\
\hline
\end{tabular}


Table 9

Undercollection of Sales Taxes

\begin{tabular}{|c|c|c|c|c|c|c|}
\hline \multirow[b]{2}{*}{ State } & \multicolumn{2}{|c|}{$\begin{array}{c}\text { Estimated State Share of } \\
\text { Quarterly Sales } \\
\text { (millions of } \$ \text { ) }\end{array}$} & \multicolumn{2}{|c|}{$\begin{array}{l}\text { Estimated Tax Liability } \\
\text { (thousands of } \$ \text { ) }\end{array}$} & \multicolumn{2}{|c|}{$\begin{array}{l}\text { Undercollection of Sales Taxes } \\
\text { (thousands of } \$ \text { ) }\end{array}$} \\
\hline & All Sellers & $\begin{array}{l}\text { Established } \\
\text { Sellers Only }\end{array}$ & $\begin{array}{c}\text { All } \\
\text { Sellers } \\
\end{array}$ & $\begin{array}{l}\text { Established } \\
\text { Sellers Only }\end{array}$ & $\begin{array}{c}\text { All } \\
\text { Sellers }\end{array}$ & $\begin{array}{l}\text { Established } \\
\text { Sellers Only }\end{array}$ \\
\hline ALABAMA & 38.96 & 7.04 & 2.83 & 2.83 & 2.83 & 2.83 \\
\hline ALASKA & 31.01 & 2.40 & NA & NA & NA & NA \\
\hline ARIZONA & 267.93 & 143.76 & 216.37 & 107.77 & 163.27 & 54.67 \\
\hline ARKANSAS & 37.14 & 11.35 & 37.33 & 37.33 & 37.33 & 37.33 \\
\hline CALIFORNIA & 1751.51 & 797.83 & 20607.46 & 8079.94 & 14128.05 & 2640.09 \\
\hline COLORADO & 112.04 & 56.48 & 4.10 & 4.10 & 0 & 0 \\
\hline CONNECTICUT & 87.61 & 40.43 & 47.78 & 10.41 & 47.78 & 10.41 \\
\hline DELAWARE & 16.22 & 5.22 & NA & NA & NA & N/A \\
\hline DISTRICT OF COLUMBIA & 11.53 & 5.72 & 0 & 0 & 0 & 0 \\
\hline FLORIDA & 660.63 & 239.97 & 4058.18 & 784.25 & 3219.20 & 556.78 \\
\hline GEORGIA & 281.66 & 129.18 & 478.74 & 232.07 & 249.49 & 2.83 \\
\hline HAWAII & 20.25 & 0.91 & 477.87 & 5.09 & 472.78 & 0 \\
\hline IDAHO & 23.63 & 6.47 & 0 & 0 & 0 & 0 \\
\hline ILLINOIS & 583.40 & 180.28 & 1594.71 & 617.80 & 1000.76 & 229.47 \\
\hline INDIANA & 185.53 & 67.15 & 289.70 & 126.50 & 144.50 & 50.10 \\
\hline IOWA & 48.95 & 8.71 & 0.70 & 0 & 0.70 & 0 \\
\hline KANSAS & 161.13 & 20.14 & 0 & 0 & 0 & 0 \\
\hline KENTUCKY & 67.13 & 16.43 & 314.25 & 0 & 314.25 & 0 \\
\hline LOUISIANA & 44.79 & 6.99 & 4.52 & 0 & 4.52 & 0 \\
\hline MAINE & 28.53 & 10.72 & 0 & 0 & 0 & 0 \\
\hline MARYLAND & 207.91 & 29.01 & 618.24 & 0 & 618.24 & 0 \\
\hline MASSACHUSETTS & 142.63 & 24.21 & 0 & 0 & 0 & 0 \\
\hline MICHIGAN & 221.40 & 31.69 & 183.60 & 20.32 & 175.11 & 11.85 \\
\hline MINNESOTA & 213.72 & 93.88 & 1316.64 & 800.47 & 516.21 & 0 \\
\hline MISSISSIPPI & 14.25 & 1.14 & 0 & 0 & 0 & 0 \\
\hline MISSOURI & 129.02 & 43.07 & 2.99 & 0 & 2.99 & \\
\hline MONTANA & 7.09 & 0.69 & NA & NA & NA & N/A \\
\hline NEBRASKA & 56.02 & 30.14 & 0 & 0 & 0 & \\
\hline NEVADA & 50.26 & 18.92 & 109.91 & 5.51 & 81.87 & 0.00 \\
\hline NEW HAMPSHIRE & 101.77 & 18.84 & NA & NA & NA & N/A \\
\hline NEW JERSEY & 360.02 & 160.10 & 1845.47 & 1473.84 & 1457.04 & 1085.43 \\
\hline NEW MEXICO & 30.02 & 4.96 & 0 & 0 & 0 & \\
\hline NEW YORK & 1041.89 & 647.17 & 2776.17 & 1540.93 & 1347.25 & 174.52 \\
\hline NORTH CAROLINA & 205.46 & 105.55 & 261.70 & 211.17 & 81.24 & 30.70 \\
\hline NORTH DAKOTA & 1.26 & 1.26 & 0 & 0 & 0 & 0 \\
\hline $\mathrm{OHIO}$ & 309.94 & 141.74 & 594.27 & 511.00 & 572.05 & 488.82 \\
\hline OKLAHOMA & 82.61 & 34.74 & 26.12 & 0 & 26.12 & 0 \\
\hline OREGON & 133.73 & 23.48 & NA & NA & NA & N/A \\
\hline PENNSYLVANIA & 441.64 & 234.34 & 1336.29 & 153.72 & 1014.39 & 1.69 \\
\hline RHODE ISLAND & 29.25 & 11.95 & 39.63 & 0 & 0 & 0 \\
\hline SOUTH CAROLINA & 75.45 & 3.01 & 21.25 & 0 & 21.25 & 0 \\
\hline SOUTH DAKOTA & 8.94 & 0.15 & 0 & 0 & 0 & 0 \\
\hline TENNESSEE & 383.89 & 293.85 & 375.38 & 262.91 & 126.68 & 14.25 \\
\hline TEXAS & 832.10 & 415.53 & 3814.72 & 1313.65 & 2489.64 & 121.59 \\
\hline UTAH & 87.63 & 41.98 & 78.32 & 11.09 & 67.28 & 0 \\
\hline VERMONT & 8.25 & 0 & 0 & 0 & 0 & 0 \\
\hline VIRGINIA & 277.62 & 106.33 & 436.67 & 291.59 & 162.78 & 17.69 \\
\hline
\end{tabular}




\begin{tabular}{lc|c|c|c|c|c} 
WASHINGTON & 438.29 & 297.86 & 1697.11 & 1566.50 & 1537.88 & 1407.31 \\
WEST VIRGINIA & 25.49 & 0.40 & 6.42 & 6.42 & 6.42 & 6.42 \\
WISCONSIN & 150.59 & 29.31 & 413.86 & 0 & 413.86 & 0 \\
WYOMING & 0.28 & 0.27 & 0.00 & 0 & 0 & 0 \\
State Unknown & 30.88 & 0 & & & & 0 \\
Taxable in All States & 141.14 & 141.14 & 141.14 & 7.04 & 0 & 6944.78 \\
\hline Total & 10700.00 & 4602.77 & 44230.45 & 18184.25 & 30503.73 & \\
\hline
\end{tabular}


Table 10

Cross-Border Shopping

(in \$ Volume of Sales between Top 15 States)

\begin{tabular}{|c|c|c|c|c|c|c|c|c|c|c|c|c|c|c|c|c|}
\hline & \multicolumn{16}{|c|}{ State } \\
\hline \multirow{16}{*}{ 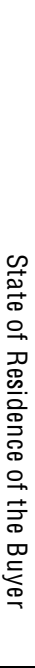 } & & $\begin{array}{l}\text { D } \\
\frac{D}{N} \\
\text { O } \\
\sum \\
D\end{array}$ & 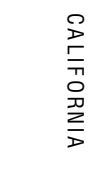 & 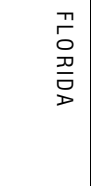 & 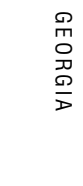 & $\begin{array}{l}\bar{\mp} \\
\bar{\Sigma} \\
\frac{0}{\infty}\end{array}$ & $\begin{array}{l}\frac{3}{\Omega} \\
\frac{1}{\Omega} \\
\geq \\
z\end{array}$ & $\begin{array}{l}3 \\
\sum \\
\sum \\
⿱ ㇒ \\
\mathbb{N} \\
0 \\
-1 \\
D\end{array}$ & 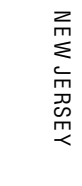 & 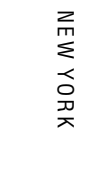 & $\begin{array}{l}\stackrel{\circ}{I} \\
\stackrel{1}{\circ}\end{array}$ & 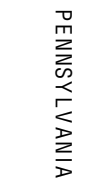 & $\begin{array}{l}-1 \\
\sum^{m} \\
\sum \\
\text { m } \\
\mathbb{N} \\
\text { m } \\
\text { m }\end{array}$ & $\begin{array}{l}-1 \\
\underset{\infty}{\times} \\
\stackrel{D}{\infty}\end{array}$ & 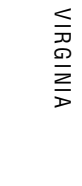 & 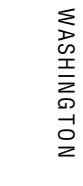 \\
\hline & ARIZONA & 272.96 & 1995.22 & 798.55 & 240.98 & 1017.04 & 209.98 & 494.55 & 249.5 & 1162.01 & 779.44 & 126.94 & 1034.05 & 343.06 & 3.21 & 420.58 \\
\hline & CALIFORNIA & 1832.9 & 20080.28 & 5327.04 & 1402.15 & 5703.44 & 1586.1 & 1699.54 & 2271.19 & 7277.95 & 2285.97 & 2354.82 & 2966.36 & 9175.39 & 2378.86 & 2953.64 \\
\hline & FLORIDA & 984.16 & 8466.71 & 4778.19 & 1465.43 & 1571.57 & 1838.41 & 814.39 & 1880.09 & 4767.07 & 949.82 & 2061.37 & 1378.85 & 2567.32 & 1231.31 & 2645.49 \\
\hline & GEORGIA & 111.75 & 2705.22 & 570.08 & 845.52 & 845.94 & 363.47 & 113.47 & 663.97 & 899.37 & 634.48 & 825.48 & 825.04 & 1810.02 & 215.5 & 607.5 \\
\hline & ILLINOIS & 603.9 & 4267.94 & 926.5 & 668.5 & 1802.54 & 790.23 & 139 & 954.44 & 1739.38 & 888.46 & 671.31 & 1361.98 & 3297.56 & 951.96 & 2693.01 \\
\hline & MICHIGAN & 101.64 & 2537.4 & 754.72 & 502.43 & 1290.85 & 216.18 & 85.24 & 904.4 & 1369.55 & 865.5 & 895.92 & 662.58 & 1881.74 & 307.59 & 732.98 \\
\hline & MINNESOTA & 340.8 & 2542.49 & 1198.43 & 521.27 & 2025.98 & 28 & 1430.99 & 282.94 & 825.17 & 75.75 & 327.6 & 456.96 & 348.42 & 842.11 & 514.77 \\
\hline & NEW JERSEY & 431.92 & 2433.69 & 2667.3 & 289.93 & 1186.28 & 173.26 & 213.96 & 1862.48 & 2028.33 & 898.79 & 1262.46 & 789.5 & 1874.5 & 264.97 & 658.47 \\
\hline & NEW YORK & 957.79 & 7196.12 & 4611.8 & 1739.83 & 3407.63 & 1214.91 & 1507 & 1510.17 & 4903.08 & 1158.8 & 1144.64 & 2331.38 & 3271.5 & 647.01 & 2504.81 \\
\hline & $\mathrm{OHIO}$ & 884.63 & 3279.39 & 1667.69 & 415.01 & 1442.38 & 853.46 & 644.5 & 1184.48 & 2748.18 & 763.31 & 331.07 & 716.51 & 2137.44 & 470.01 & 1114.44 \\
\hline & PENNSYLVANIA & 948.42 & 4363.22 & 1714.9 & 413.48 & 1258.51 & 573.3 & 757.25 & 938.97 & 3964.35 & 573.57 & 1573.38 & 1330.88 & 2364.09 & 1058 & 596.79 \\
\hline & TENNESSEE & 169.6 & 1871.26 & 673.68 & 1586.48 & 558.01 & 42.99 & 19.99 & 379.02 & 2037.05 & 996.93 & 1166.49 & 378.84 & 467.13 & 139.98 & 155.25 \\
\hline & TEXAS & 585.76 & 9737.04 & 4027.43 & 1141.64 & 1089.62 & 734.23 & 2368.88 & 1054.43 & 4070 & 1965.54 & 1855.84 & 863.8 & 4311.87 & 1040.83 & 1400.32 \\
\hline & VIRGINIA & 747.34 & 2317.54 & 470.23 & 84.5 & 260 & 292.27 & 138 & 1471.57 & 2151.53 & 99.13 & 161.77 & 1114.3 & 2043.75 & 616.97 & 161.26 \\
\hline & WASHINGTON & 362.59 & 2535.45 & 505.31 & 1261.22 & 162.06 & 333.5 & 80.99 & 180.98 & 1525.14 & 39.95 & 687.76 & 653.47 & 571.67 & 2293.81 & 1844.51 \\
\hline
\end{tabular}


Table 11

Seller Characteristics and the Decision to Collect Sales Taxes ${ }^{\mathbf{a}}$

\begin{tabular}{lcc|cc}
\hline \multirow{2}{*}{$\begin{array}{l}\text { Independent } \\
\text { Variable }\end{array}$} & \multicolumn{2}{|c|}{ Specification I } & \multicolumn{2}{c}{ Specification II } \\
\cline { 2 - 5 } Coefficient & Marginal & Coefficient & Marginal \\
(Standard Error) & Effect & Standard Error) & Effect \\
\hline Seller Rating & $5.33 \mathrm{E}-05$ & $1.42 \mathrm{E}-05$ & $4.81 \mathrm{E}-05$ & $1.30 \mathrm{E}-05$ \\
& $(2.61 \mathrm{E}-06)$ & & $(1.50 \mathrm{E}-06)$ & \\
& 0.0343 & 0.0092 & 0.0690 & 0.0187 \\
Seller Rating Percent Observations & $(0.0136)$ & & $(0.0097)$ & \\
& 0.0150 & 0.0039 & 0.0004 & 0.0001 \\
Price & $(0.0019)$ & & $(0.0002)$ & \\
& & $-8.6 \mathrm{E}-05$ & $-2.30 \mathrm{E}-05$ \\
Shipping Charge & & $(0.0001)$ & \\
& & & 0.0015 & 0.0003 \\
Constant & -4.5462 & & $-0.0007)$ & \\
& $(1.3538)$ & & $(0.9055$ & \\
\hline LR $\chi^{2}$ & 782.98 & & 1477.24 & \\
Observations & 6465 & & 18863 & \\
\hline
\end{tabular}

${ }^{\mathbf{a}}$ The dependent variable in both specifications is Taxation.

Figure 1

Sales Tax Compliance Rate by Seller's Rating

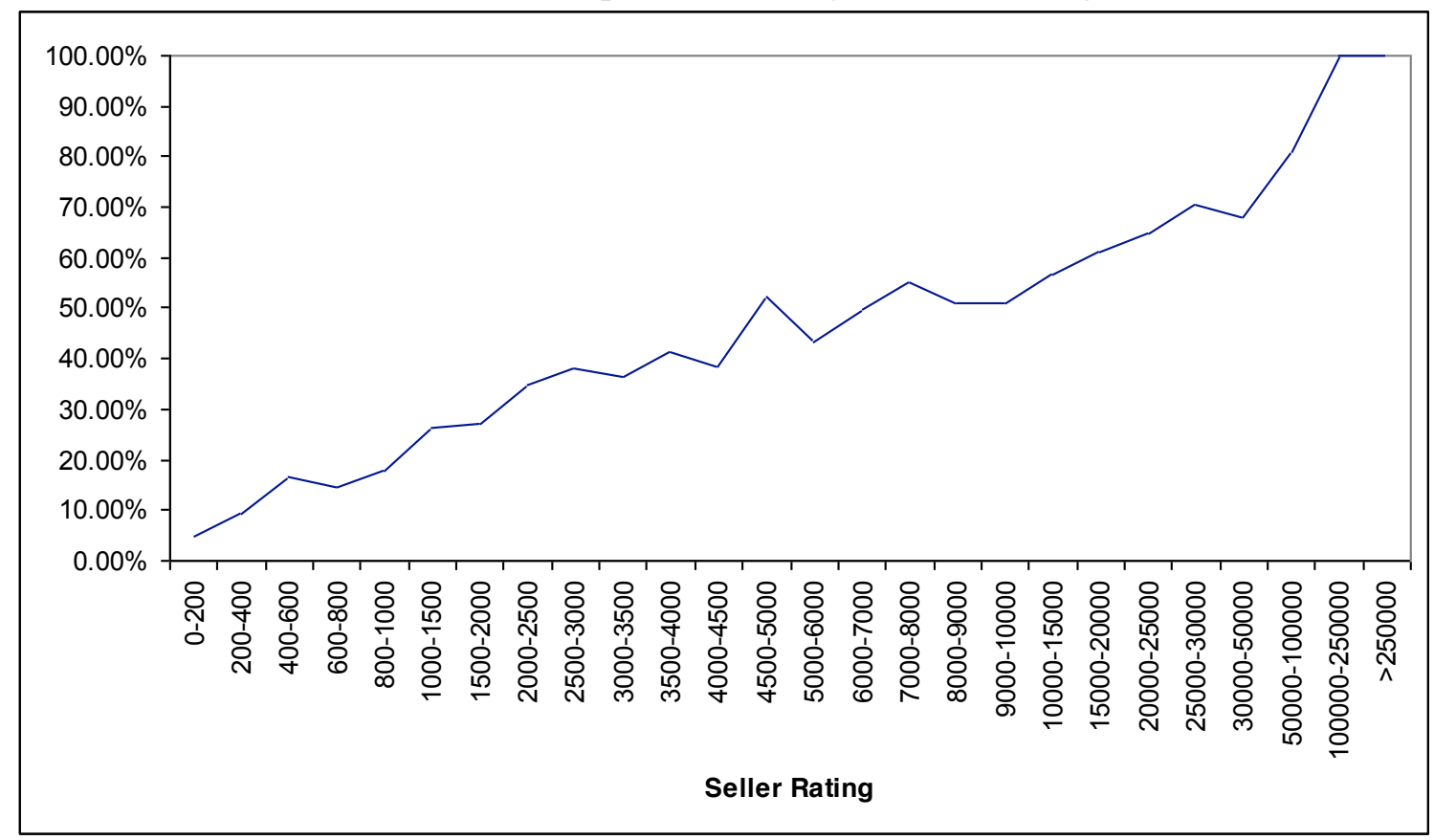

